\title{
Grasping the Discrete Link between Filming and Videoconferencing in the Courtroom. Reflections from the French Case
}

Compreender a ténue ligação entre a filmagem e a transmissão numa sala de audiências. Considerações sobre o caso francês

Saisir le lien discret entre filmer et réaliser une visioconférence dans une salle d'audience. Réflexions à partir du cas français

Laurence Dumoulin and Christian Licoppe

\section{OpenEdition}

Electronic version

URL: http://journals.openedition.org/rccs/6608

DOI: $10.4000 /$ rccs. 6608

ISSN: 2182-7435

Publisher

Centro de Estudos Sociais da Universidade de Coimbra

Printed version

Date of publication: 1 May 2017

Number of pages: 115-134

ISSN: 0254-1106

Electronic reference

Laurence Dumoulin and Christian Licoppe, « Grasping the Discrete Link between Filming and Videoconferencing in the Courtroom. Reflections from the French Case ", Revista Crítica de Ciências Sociais [Online], 112 | 2017, Online since 15 May 2017, connection on 20 April 2019. URL : http:// journals.openedition.org/rccs/6608; DOI : 10.4000/rccs.6608 


\section{LAURENCE DUMOULIN, CHRISTIAN LICOPPE}

\section{Grasping the Discrete Link between Filming and Videoconferencing in the Courtroom. Reflections from the French Case*}

Filming and transmitting hearings on the one hand, and conducting them by videoconferencing on the other, are generally addressed through different issues and analytical lenses. In this paper we have used the French experience to show that, in fact, the two activities have some features in common. We have tried to highlight the real but discreet empirical connections between them in France and to underscore a few convergent issues with regard to the concept of a trial and the various conceptions of both presence at and participation in a hearing, as well as of publicness.

Keywords: broadcast; filming; judicial hearings; law; videoconferencing.

Filming a trial to make it public and using videoconferencing to allow specified parties to take part in it seem to serve two radically different purposes. The former aims to produce a record of an activity for wider dissemination; the latter mediates the parties' participation in the trial, creating a new way to appear at a trial. In consequence, these two issues are generally not addressed together: the existing literature deals with them separately, from the "Law and Film" perspective of filming and, with respect to videoconferencing, from the angle of transforming trials and the act of adjudication.

The aim of this article is to connect these two empirical subjects in order to show that in the French case, they are discreetly linked and influence each other. This leads us to draw an analytical reflection on the judicial use of camera technology in the courtroom.

* The authors are grateful to all the actors and institutions who participated in this research. The research was funded by the French National Research Agency (ANR), Programme Blanc, Visiojustice Project and by the GIP Mission de recherche Droit et Justice. The authors are also grateful to the two anonymous reviewers who helped improve the paper and to the editing team of the journal. 
Since the post-World War II period and except in a few, clearly identified cases, French positive law has prohibited recording trials once they have begun, regardless of the medium (audio, photo, video). Sometimes described as nationally specific, this situation is a cause of debate in France. The issue has been on the political agenda in the 2000s but although there has been some movement, recording hearings remained prohibited except in rare cases. In this context, the introduction of videoconferencing at the end of the 1990s could have offered an opportunity to fuel the debate on the general principles of trial and the status of images in the justice system. But it has not and that has been puzzling.

In the first instance our research focused on hearings by videoconferencing. We performed in-depth research on videoconferencing, and collected a large corpus of sources. We were authorized to record hearings in two examination chambers in connection with our sociological research on the origin and uses of videoconferencing in French criminal trials. ${ }^{1}$ This is how we experienced the prospects opened by filming trials. So we noticed that while filming trials in France is still generally prohibited, it was possible to obtain exceptional authorization.

Having overviewed the existing literature (1), we will present our methodology (2). We will then summarize the French history with regard to filming trials, in order to establish the fact that it is a very controversial matter (3). We will then cover the genesis of videoconferencing for French judicial hearings in order to argue that this innovation was designed in such a way that any link to recording was denied. We will provide evidence that videoconferencing questions the status afforded to trials, in particular from the standpoint of publicness, and destabilizes the conception of a public hearing on which the 1881 legislation lies (4). In conclusion, we will argue for the advantages of trying to address the different aspects of technological change in the same movement, even when they seem to differ.

\section{State of the Art}

Law and Film studies has been developing since the 1990s in the United States and more widely through international research articles published in English (Machura and Robson, 2001; Silbey, 2001). This sub-field within the Law and Society movement has three facets that reflect the various

\footnotetext{
${ }^{1}$ Videoconferencing is a sociotechnical procedure that establishes both an audio and a visual connection between two sites. In the case of judicial proceedings, it allows hearings to be held in which some of the parties are in court and others are in a videoconferencing room at another site within the legal system, for instance a prison, or a hospital.
} 
relationships between the legal and judicial world on the one hand, and images, visual and audiovisual communication technology on the other.

The first body of literature concerns the way in which the courts and legal professionals are represented in popular culture, particularly in films and TV series (Sherwin 2004; Miniato and Flores-Lonjou, 2013; Villez, 2009). Such an approach is an extension of Law and Literature studies, but is based on audiovisual productions - usually fictional - rather than novels. This field is also directly related to cultural studies, that is, to a tradition of research that focuses on the way law and culture, and popular culture in particular, interact. The trial film has thus been analyzed as a specific genre with certain narrative and staging features (Silbey, 2002, 2004).

The second body of research examines the role played by visual and digital technologies in the legal culture (Feigenson and Spiesel, 2009; Porter, 2014; Sherwin, 2000). It remains clear that writing predominates almost entirely without competition, but legal and judicial activity cannot avoid being brought into the digital age (Porter, 2014). Some research focuses on surveying the practices developed by those who are considered "pioneers" (Feigenson and Spiesel, 2009). Some lawyers and judges have started incorporating visual arguments into their submissions or oral arguments: images, photographs, screen shots from video-surveillance or embedded cameras, etc. The authors also comment on the rare fragments of ethical and legal guidelines that can be found in the case law. Lastly, they analyze the important changes affecting the processes of narration and argumentation and also the methods for managing evidence, as audiovisual tools (tablets, smart phones, etc.) become more widely available and visual technologies gain new features as well as greater power and capacity. ${ }^{2}$

The third line of research analyzes how the law governs audiovisual productions regarding court activities, and in particular the work of regulating the terms for filming and broadcasting trials by the general media or by specialized channels. In the United States, the 1980s saw the decision in Chandler v. Florida, which authorized the constituent states (in this case, Florida) to begin filming and broadcasting trials held in state courts, even when the accused does not consent. Numerous law review articles discussed this decision, pointing to the possible risks of opening up the courts to the cameras (Ares, 1981; Camp, 1982; Nesson and Koblenz, 1981; Patterson, 1982; Garthwaite, 2014). Since that time, ongoing hearings may be

\footnotetext{
${ }^{2}$ Not only photographs and videos, but also image-processing software, such as Photoshop, animation and three-dimensional representation software, multimedia and interactive technologies, etc.
} 
broadcast, and some television channels - e.g. Court TV, created in the early 1990s - specialize in the live broadcast of trials. Several high-profile trials were broadcast live in their entirety, fuelling controversy over how mediatization affected the behavior of judges, jurors, and witnesses. The issue raised in connection with state courts then moved on to the federal courts and was the subject of research in the United States (Marder, 2011; Adkins, 2010) and also in France (Humbert, 2010; Sécail, 2010; Epineuse et al., 2010).

Concerning videoconferencing, it has been used in many courtrooms in a wide variety of situations since the 1990s (Surette, 2007; Lederer, 2005, 2009; Wiggins, 2006). Many countries have adopted it, including the United States, Canada, Australia, Great Britain, Italy and the Netherlands (Lanzara and Patriotta, 2001; Lederer, 2005; Wallace, 2008; Henning and $\mathrm{Ng}$, 2009). Some publications (Babcock and Johansen, 2011; Biolley, 2013; Bossan, 2011; Braun, 2013; Danet, 2010; Diamond et al., 2010; Dumoulin and Licoppe, 2013; Gertner, 2004; Garofano, 2007; Henning and Ng, 2009; Kodek, 2012; Rowden, 2013; Salyzyn, 2012; Wallace, 2008) have identified several major areas of concern with the use of videoconferencing, in particular in the field of criminal law (Dumoulin and Licoppe, 2016: 315-318).

First, the question of the compatibility of videoconferencing with prevailing legal regulations has been raised, in view of the different legal, judicial situations and within different national systems (Babcock and Johansen, 2011; Bossan, 2011; Dumoulin and Licoppe, 2013; Gertner, 2004; Wiggins, 2003; Wallace, 2008). The question of whether appearing remotely and in co-presence can be considered as equivalent, has also been analyzed from the viewpoint of the quality and depth of judicial interactions (Mulcahy, 2010; Danet, 2010). Finally, the symbolic and political challenges of videoconferencing for the meaning of a public hearing have also been pointed out (Mulcahy, 2010). A trial is a type of scenography, a drama that reenacts the conflict and operates according to a process of catharsis (Garapon, 2001). The respective positions of the victim, the accused and the witness reflect a real distribution of roles in the trial process. To distance one participant - whether a witness or the accused and their counsel - by allowing them to contribute to the hearing from another place destabilizes this symbolic economy of justice without proposing any alternative, positioning it somewhere outside the spatial organization of the trial.

Research into the connection between filming trials and using videoconferencing is rare. Videoconferencing is not absent from Law and Film studies (for example: Feigenson and Spiesel, 2009: 170-171), however the concrete links and crossed-influences between filming-broadcasting and performing videoconferencing hearings have not been adequately analyzed. 
Our article is born from what we observed during our empirical work on videoconferencing. We realized that the discussions of what was controversial concerning filming the trials were not taking place with reference to videoconferencing. Yet, videoconferencing could be used for recording hearings; it is technically possible. So logically the same kind of controversy should have arisen concerning videoconferencing. But this was not the case. Why are these two forms of introducing a camera in the courtroom seen as equally problematic? That is what we are going to consider immediately after we describe our methodology.

\section{Methodology}

For several years, we have been following the introduction and the institutionalization of videoconferencing in various judicial settings in France. Our approach is primarily qualitative and concerns a diverse range of methods. Broadly speaking, the research protocol was initially based on a historical perspective with work on written traces (archives, bills, bodies of laws and parliamentary debates, institutional publications, news reports and articles). It also involved semi-structured interviews with a number of stakeholders. Lastly, it includes an ethnographic approach conducted through direct observation of judicial hearings and video recording of some of them. Our fieldwork involved four Appeal Courts (cours d'appel), two in mainland France (Grenoble and Rennes) and two overseas (Saint-Pierre-et-Miquelon and Saint-Denis de la Réunion).

To be more precise, the fieldwork concerning the four cases encompasses a hundred and twenty interviews with different types of actors: judges, lawyers, attorneys, clerks and clerks' secretaries, hearing bailiffs, agents from the French, Ministry of Justice, all of whom had either participated in the legal framing of videoconferencing or had recently taken part in hearings by videoconferencing. We were able to attend numerous remote hearings in several types of French jurisdictions (notably the criminal courts for felonies ${ }^{3}$ and for misdemeanors ${ }^{4}$ and the examination chamber of the Appeal Court). It is important to emphasize this point as it allowed us to observe different types of legal performance mediated by the videoconference technology (defendants' appearances, lawyers' oral arguments, witnesses' testimonies, etc.). We filmed some of them (65 cases of appearances via videoconference; 20 cases of physical attendance were observed and/or filmed; while 16 cases took place without any appearance of the individual, from file).

\footnotetext{
3 The cour d'assises.

${ }^{4}$ The tribunal correctionnel.
} 
All of this provided us with a profoundly in-depth analysis, replete with empirical data. Only a part of this immense body of material is being used in this article.

On the French historical background of the filming issue, we re-constructed the French controversy by collecting legal texts and pronouncements, parliamentary debates, press clippings and secondary documents.

\section{Filming Hearings: A Still Controversial Matter in France}

Cameras are allowed in courtrooms in a wide variety of situations in Europe. From the late 1980s, this practice has spread from Italy, to Spain ${ }^{5}$ and to the United Kingdom (Stepniak, 2004). Each system specifically defines the courts concerned, the requirements for filming and/or broadcasting images, and the use that may be made of them. Meanwhile international courts such as the European Court of Human Rights systematically make audio-visual recordings of hearings and broadcast them on the internet.

France, for one, seems to take a different position. The rule is that cameras are prohibited regardless of the type of court (civil, criminal, or administrative) and regardless of whether the intended use is internal (records for the parties to the proceeding or for the court) or external (for the media and the general public). No recording, no filming and no broadcasting, whether live or pre-recorded. But in addition to the fact that this prohibition has not always been enforced, it has been implemented in ways that have (practically) stripped it of any meaning.

\section{Flashback}

"Until the mid-20 $0^{\text {th }}$ century, freedom of the press was the rule with regard to mediatization of trials" (Sécail, 2010:270). Photographers and press and radio journalists were allowed to attend trials and take photographs, make sketches or make recordings throughout the proceeding. The presiding judge could of course invoke his or her police powers and deny journalists access to the courtroom, but this was rarely done. In fact, in "major criminal cases" that garnered a lot of media attention, the courtrooms were full of journalists equipped with recording devices moving around the room and punctuating key moments of the trial with numerous flashes. In the 1930s, various politicians began calling for regulations to limit journalists' access to courtrooms and the attendant mediatization, which was considered contrary to the decorum of a trial. But it wasn't until the post-war period that

\footnotetext{
${ }_{5}$ For civil matters, Act no. 1/2000 of 7 January 2000, enforced since 7 January 2001 and for criminal matters, Act no. 13/2009, enforced since 5 May 2010 (Garre, 2013).
} 
the issue was raised again, with the very highly publicized criminal trials of Marie Besnard (1952 and 1954) and Gaston Dominici (1954).

At that time, a change in the law was suggested to institute a rule prohibiting recordings while allowing the Minister of Justice to grant occasional exceptions. Two main arguments were made. The first was that doing justice requires dignity and decorum in the courtroom. These are necessary in order for trials to be properly conducted, and are also the hallmarks of respect for the court's authority, without which trials would not have the same reach. The second was that the presence of journalists during a trial was harmful, mainly to the accused. The point was therefore to protect the defendant - and the other participants - because "regardless of how serious the accusations or threats against him, he has the right to all legal means and not to be transformed into the spectacle of a hunted animal". ${ }^{6}$ Those who argued for this reform, which aimed to keep photographers and audio-visual journalists out of the courtroom, therefore thought of it as regulating practices that affect the "publicness of trials" ${ }^{7}$ rather than as an infringement of this rule. We will come back to this later. For now we will simply note that during the parliamentary debates, few divisions or differences of opinion were expressed with regard to this view of publicness or any other aspects of the proposal: the prohibition seems to have been the object of consensus among lawmakers across political parties. ${ }^{8}$

Prohibition was therefore established as the rule in a 1954 law $^{9}$ that amended Article 38c of the general law of 29 July 1881 on freedom of the press. ${ }^{10}$ That article provides that

as soon as a trial begins in an administrative court or civil/criminal court, use of a device that makes it possible to transmit images is prohibited, and the presiding judge of the court is authorized to have any device used in violation of this rule seized and confiscated. ${ }^{11}$

\footnotetext{
${ }^{6}$ Journal offciel, Fourth Republic, Council of the Republic, Parliamentary debates, Session of 29 June 1954, p. 1181.

7 This is shown by the fact that this reform was entitled "Publicness of trials" when it was submitted to the National Assembly for the first round of discussions: Journal officiel, Fourth Republic, National Assembly, Session of 2 March 1954, voted on and adopted without discussion of bill no. 5353 , p. 588 .

${ }^{8}$ The only issue discussed was who should be able to authorize picture taking: the judge presiding over the trial or the Minister of Justice. It was finally agreed that it should be the latter.

96 December 1954 Act.

${ }_{10}$ Act concerning the freedom of the press of 29 July 1881, Journal officiel, 30 July 1881, p. 4201.

${ }_{11}$ Art. 38c of the 1881 Act concerning the freedom of the press.
} 
Adopted shortly thereafter - with the launching of a new Criminal Procedure Code in 1958 -, Article 308 of the French Criminal Procedure Code, which concerns the criminal courts, strengthened the prohibition and modified the 1954 Act, only four years after it was adopted, and is still in force: "as soon as a trial begins, use of any sound recording or broadcasting device, television or movie camera, or photographic camera is prohibited, subject to a fine of 18,000 euros". ${ }^{2}$

\section{Exceptions Multiply}

Established in the mid-1950s, this theoretical prohibition has in fact been weakened, as the rule has been relaxed in some situations and exceptions have been created. It was first relaxed in 1981 through the so-called "Security and Freedom" act, which allows trial judges to authorize journalists to take pictures before a trial begins, provided the persons concerned consent. ${ }^{13}$ Cameras thus entered some courtrooms but could not film the trial, only the preparations, most frequently, the parties taking their places. And in the case of the felony courts, this law gave trial judges the power to have sound recordings made that would be placed under seal and, if necessary, could be used in the future. It is still possible to make such sound recordings, but only some of the courtrooms in the felony courts (about half in 2015) have been fitted with recording equipment.

In addition, an exception was created a few years later by a law that allows trials to be recorded "in connection with creating the legal system's historical archives" ${ }^{14}$ Pursuant to this law, several major trials have been recorded, in particular trials for crimes against humanity. ${ }^{15}$ In practice, however, this law has not been invoked to obtain permission to record ordinary trials even though they could easily be placed within its scope by arguing that they are of historical and sociological interest. This possibility has therefore never become a reality, which one defender of the law in fact regrets (Badinter and Wievorka, 2002).

Despite these statutory provisions, in the 1990s filming began to be authorized occasionally by judges and their supervisors, by the courts' chief justices, and sometimes by the Ministry of Justice. Thus several

\footnotetext{
${ }^{12}$ Criminal Procedure Code, Art. 308, modified by later legal instruments but still in force.

13 Act no. 81-82 of 2 February 1981, enhancing security and protecting personal freedom, Journal officiel, 3 February 1981, p. 415.

${ }^{14}$ Act no. 85-699 of 11 July 1985 on the Creation of audiovisual archives of the legal system, Journal Officiel, 12 July 1985, p. 7885.

${ }^{15}$ See, for example, the trials of Klaus Barbie (1987), Paul Touvier (1994) and Maurice Papon (1997-1998). The films may then be broadcast after periods that vary depending on the nature of the case and subject to the approval of the chief judge of the Court of First Instance of Paris.
} 
French documentaries were made and shown by television stations and in movie theatres.

However, this dual regime is not easy to defend. Journalists are put in an uncomfortable position of inequality and dependence vis-à-vis judges. Since any authorization they receive is an exception, it is subject to discretion at every level of the system and can be revoked depending on the context. In the legal domain uncertainty reigns. Moreover, how can we justify the fact that the rule is bent by occasional authorizations that institute a form of inequality among journalists and between different media? A number of people have taken the popular and highly publicized success of the film $10^{\circ}$ chambre. Instants d'audience $\left[10^{\text {th }}\right.$ Chamber: Scenes from a Trial], which was selected to be shown at the Cannes film festival, as an opportunity to reopen the debate.

\section{3-2005: A Window of Opportunity Opens and Shuts}

After this film, the Minister of Justice, who favored changing the law, set up a working group in the central judicial administration to examine the issue of cameras and microphones in courtrooms. The working group "suggested authorizing recording and broadcasting hearings solely for the purposes of making instructional documentaries and subject to meeting certain requirements", and the minister then tasked a commission made up of judiciary and media representatives to examine the issues and make concrete proposals (Coulon, 2004). This commission, called the Linden Commission after the judge who chaired it, issued a report in 2005 in which it very clearly supported creating a system of prior approval to allow cameras in the courtroom and to broadcast trials under certain conditions (consent of the parties, broadcasting entire trials, etc.). ${ }^{16}$ The commission and its report received a lot of publicity through events, $\operatorname{blogs}^{17}$ and the publication of reports in the general and specialized press. ${ }^{18}$ The Supervisory Board of the Judiciary supported the Linden Commission's proposals and made that support known in its 2007 report. ${ }^{19}$ At the same time, the judges of the Paris Court of Appeal spoke out publicly, stating that they approved of

\footnotetext{
${ }_{16}$ Ministry of Justice (2005), Rapport de la commission sur l'enregistrement et la diffusion des débats judiciaires, 22 February. Accessed on 21.03.2017, at http://www.ladocumentationfrancaise.fr/var/ storage/rapports-publics/054000143.pdf.

${ }_{17}$ Maître Eolas, "Fenêtre sur prétoire", 18 January 2008. Accessed on 21.03.2017, at http://www. maitre-eolas.fr/post/2008/01/18/844-fenetre-sur-pretoire.

${ }^{18}$ For example: "La justice sous l'œil des caméras", Droit \& Economie, Revue de l'association française des docteurs en droit, 92, November 2004, p. 6-9.

${ }_{19}$ Laurence de Charrette, "Le Conseil supérieur de la magistrature favorable aux caméras dans les prétoires”, Le Figaro, 23 October 2008.
} 
the Commission's proposals on the grounds of performance. The press relayed their thinking and discussions and published special articles and in-depth reports. ${ }^{20}$ And yet nothing changed; the project got bogged down and the issue was struck from the political agenda and has hardly been raised since. ${ }^{21}$

The controversy reached a peak between 2005 and 2010 in France, but it now seems to be dormant, having lost its visibility and disappeared from public discourse. However, that does not mean it is dead. On the contrary, while the issue of filming trials is no longer on the agenda for the media industry or politicians, the judicial system and those who work in it are faced with cameras and microphones from other sources, and these innovations have been held up as precedents for all concerned.

\section{The Genesis of Hearings by Videoconferencing}

The debate over filming and broadcasting trials is really just one of the facets of the issue of using audiovisual technologies in the legal field. A close observer will find connections between the various controversies and developments that have brought new ways of thinking to the judicial system and the act of adjudication. The issue of cameras and microphones was raised in the 1990s by way of the question of recording individuals during police custody. The first use of such technology was to film victims who were minors giving their statements for possible replay at trial. The period between 2000 and 2010 saw the proliferation of trials by videoconferencing, and beginning in the mid-2010s, audiovisual recording of felony trials became mandatory. These developments may not seem to be connected at first blush, but they do in fact have an effect on each other and are not unrelated. In addition, they have all helped give the trial a new status by giving new meaning to "appearance" and "public trial" and providing new methods to achieve them.

\section{Cameras, Mics, and Screens: Interrelated Media Devices}

As the debates raged regarding the wisdom of allowing trials to be filmed by the media, some sequences of criminal proceedings were subjected to forms of image and/or sound capture by the criminal investigation or judicial

\footnotetext{
${ }^{20}$ France Info, "Le débat sur les procès filmés est relancé", 17.01.2008; "Pour une chaîne justice", Libération, 24.11.2008; "Des caméras dans le prétoire?", special report, Le Monde, "Télévisions" supplement, 14-15 December 2008, p. 8.

${ }^{21}$ Occasionally, the question is revived. See for example: Isabelle Hanne, "Caméras côté cour", Libération, 7 December 2009, accessed on 21.03.2017 http://www.liberation.fr/medias/2009/12/07/ camera-cote-cour_597796, or Bussy and Bragança (2012).
} 
authorities themselves. In the 1990s, the justice think tank proposed making sound recordings of all individuals held in police custody. The idea was set aside in the face of opposition, except for the questioning of minors who were the victims of sex offenses (Sontag-Koenig, 2012: 527), for whom recording was not only authorized but made mandatory in $1998 .{ }^{22}$ The main argument for this is that recording protects these particularly fragile victims: it spares them the need to repeat their allegations several times and in detail, and prevents the questioning, with its adversarial nature (confrontation with the accused and their account of the events; exposure to the public, etc.), from becoming an additional trauma or even re-victimization.

The 1998 law is important for two reasons. It provided a first technological solution that was then repeated and extended to other situations: police custody of minor suspects, ${ }^{23}$ then the questioning of individuals placed in police custody for a felony. ${ }^{24}$ Secondly, it creates a separation in French law between taking part in and being physically present at a trial. A victim's testimony can be heard and therefore taken into account at trial even though the person concerned is not there.

This legal recognition of the ability to remove one of the participants from the tria ${ }^{25}$ was then invoked as a precedent in the legal arguments over using videoconferencing to hold trials between Paris and Saint-Pierre-et-Miquelon. ${ }^{26}$ In support of videoconferencing, several memos from the Ministry of Justice mention the recording of the questioning of minors and the law of 17 June 1998. ${ }^{27}$ That precedent was also highlighted during the discussions before the State Council (Conseil d'Etat). This provision was used as a standard attesting to the fact that it is no longer legally unthinkable that a trial can take place without all of the participants being physically present. And a few years later, when the issue of creating a room specifically for videoconferencing at the courthouse in Paris arose, the arguments in favour emphasized not only the variety of uses to which the room could be put but

\footnotetext{
${ }^{22}$ French Criminal Procedure Code Article 706-52(3)-(8) regarding the recording of the questioning of underage victims of certain sex offenses.

${ }^{23}$ Obligation written into Art. 4-VI of Ordinance no. 45-174 of 2 Feb. 1945 regarding juvenile delinquency by law no. 2000-516 of 15 June 2000 strengthening the protection of the presumption of innocence and victims' rights.

${ }^{24}$ French Criminal Procedure Code Art. 64-1, inserted into the Code by law no. 2007-291 of 5 March 2007 tending toward the creation of a more even balance in criminal procedure. In addition, Article 116-1 of this law provides for interrogations of criminal suspects to be recorded.

${ }^{25}$ In practice, this is far from systematic.

${ }^{26}$ For a more thorough discussion of this case, see Dumoulin and Licoppe (2016: 320-321).

${ }^{27}$ French State Council Archives, Memo from the Office of Human Rights of the Ministry of Justice, undated (but circa 1998); memo of 22 June 1998; confirmed during an interview with the AB1 office drafting judge, 14 June 2006.
} 
also the fact that "video footage" could be "record[ed] or project[ed]", citing the "testimony of underage victims of sexual aggression" 28 as an example. Connections are therefore occasionally made, which also means, symmetrically, that some possible connections have not been made. Because it establishes a connection whereby images and sound are transmitted between two sites, providing for trials by videoconferencing could have been an opportunity to revive the debate on recording trials in general. That did not happen, however. The discussion before the State Council regarding videoconferencing was so tense that the issue of recording hearings in general, which is technically possible, was omitted. The promoters did their best to prevent the issue from emerging - by assuring that videoconferencing would not be used for recording, which was prohibited by the 1881 act, modified in 1954 . Thus, when the time came to regulate the practical terms for holding videoconferences between Paris and Saint-Pierre-et-Miquelon, a

regulation set out the technical requirements for implementing videoconferencing while stipulating that recording images and sound be punished according to the law [of 1881] and that an order issued jointly by the Minister of Justice, the Minister of the Interior, and the Minister of Defense [enumerate] the technical features for transmissions, to protect the confidentiality of the transmissions and make sure that the images of the trial are not kept. ${ }^{29}$

The technical possibilities are therefore limited by the state of the law, and the law of 1881 (modified by the 1954 Act) seems to provide a prior, indirect framework for videoconferencing. But the reform of videoconferencing caused a discreet shift: the law of 1881 as modified by the 1954 Act "proscribes and punishes the recording, fixing, and transmitting of the words, sounds, or images of a trial by means of any device", but videoconferencing in fact introduced an exception because it necessarily involves audiovisual transmission. ${ }^{30}$ Videoconferencing was thus introduced and has evolved by creating exceptional practices that de facto, and without necessarily saying as much, reduce the scope of the prohibition contained in the law of 1881

\footnotetext{
${ }^{28}$ Paris Court of Appeal Archives (2002), Report of the Meeting of 5 February 2002 Concerning Creation of a Videoconferencing Room. Paris: Real Estate Department of the Courthouse of Paris, 12 February, p. 2.

${ }^{29}$ French State Council Archives, Letter sending the draft decree from the Minister of Justice to the State Council, 22 November 2000, p. 2.

${ }^{30}$ As the decree's rapporteur before the State Council emphasized, "transmission [is] expressly and exceptionally authorized by the ordinance itself", French State Council Archives, File 365585, Report on the decree implementing ordinance no. 98-729 of 20 August 1998, December 2000, p. 3.
} 
modified by the 1954 Act. In this sense, therefore, videoconferencing constitutes an additional step toward undermining the prohibition to capture, record, and transmit trials.

In addition, while the 1998 ordinance, which applies solely to the case of Saint-Pierre-et-Miquelon, does not address the issue of recordings, a generally applicable provision adopted three years later does. It indicates that operations conducted by videoconferencing "may be subject to audiovisual or sound recording". ${ }^{31}$ The applicable rules are those provided for recording the questioning of underage victims of sex offenses. ${ }^{32}$

This clearly shows the extent to which the scope of the rule prohibiting the recording of trials is being reduced concurrently with the introduction of new audio-visual devices that in fact have little to do with it.

Moreover, starting in the mid-2010s, this time in the context of the felony courts, the procedure for revising criminal sentences was changed, so that opening a trial for revision is now subject to a single criterion: "the existence of a new fact or information that was unknown to the court at the time of trial and is likely to establish the innocence of the defendant or raise doubt about his or her guilt". ${ }^{33}$ To determine whether the information is new, one needs detailed knowledge of what was said during the original trial. That is why provision was made for trials to be the object of sound recordings that were then placed under seal and kept in the court's archives: this made it possible to keep a record of the twists and turns of oral proceedings, that until then were preserved only in written transcripts. Sound recordings are mandatory subject to the judgment being void, ${ }^{34}$ but may be replaced by an audiovisual recording.

In short, courtroom activity now incorporates a variety of audio and visual technologies, all of which weaken the rule that trials cannot be filmed and/or broadcast.

\section{New Ways to Appear at Trials and Make Trials Public}

But there's more. The classic public trial is a drama in which all the characters appear in the same place at the same time. The simultaneous presence

\footnotetext{
${ }^{31}$ French Criminal Procedure Code Article 706-71, created by law no. 2001-1062 of 15 November 2001.

32 French Criminal Procedure Code Article 706-52(3)-(8).

${ }_{33}$ Act no. 2014-640 of 20 June 2014 concerning the reform of revision procedures and reassessment of final criminal sentences, Journal Officiel, 21 June 2014.

34 The law of 2014 provided that such recording was merely suggested, not required subject to invalidity. But that provision was submitted to the French Constitutional Council for a preliminary ruling and declared unconstitutional (decision of 20 November 2015). Sound recordings of felony trials thus became a right.
} 
of the various parties to the conflict gives the trial its meaning (Garapon, 2001). Publicness is conceived of as the ability of citizens, members of the political community, to attend the trial.

If we go back to the parliamentary debates over the 1954 Act (which modified the 1881 law), we see that this conception of the trial in general, and public trials in particular, is explicit. The rapporteurs of the bill on prohibiting the filming of trials agreed to define the concept of "publicness" as the theoretical and practical ability of every citizen to attend judicial proceedings: "In a democracy such as ours, public trials are the rule. The aim is to enable any citizen to see how other citizens are tried and sentenced or acquitted" (Minjoz, 1954: 5637). The rule that trials are public does not necessarily mean that those working for the media can relay what happens inside the courtroom through photographs or audiovisual recordings. One of the bill's rapporteurs stated that

[i]f anyone objects that the presence of photographers, and soon perhaps television and radio-broadcasting devices, is a consequence of the rule that trials and hearings shall be public, it must be pointed out that such publicness is sufficiently guaranteed by the presence of the public in the courtroom. (Minjoz, 1953: 53)

On this view, trials are made public only by the direct, immediate presence of citizens and members of the press in the courtroom. They act as eyewitnesses to the trial and thereby give substance to the rule requiring that trials be public. The relaying of the trial by journalists, who are external third parties, is therefore superfluous.

But can the public's physical presence still be the only guarantee of publicness when trials are no longer strictly defined by the principle of the simultaneous presence of the parties to the trial? Isn't there a kind of hiatus here?

If we take the case of videoconferencing, it is clear that its development has meant that physical presence is no longer seen as the only full and complete form of presence. Firstly, some trials occur without co-presence, and the number of such trials is increasing. Secondly, for such trials to take place, they had to be made legal by changes in the law. Legislative provisions that extended videoconferencing to all or almost all types of disputes have given remote appearance the same legal status as physical appearance. ${ }^{35}$ As the French Court of Cassation frequently reiterates, appearance through

\footnotetext{
${ }^{35}$ Circular no. 2007-09 of 25 May 2007, specifying, in particular, the scope of Article 70 of the law of 5 March 2007 on crime prevention.
} 
videoconferencing is deemed to be a mode of personal appearance. ${ }^{36}$ In other words, in theory, remote appearance constitutes personal appearance under French law.

But what is more, this new principle of equivalence has indirectly established that physical presence is no longer the only way to enter a personal appearance. Physical attendance at trial has therefore become increasingly unnecessary and less important. The notion of a public hearing itself is therefore no longer exactly what it used to be. Consequently, the introduction of videoconferencing affects not only the state of the law, but also the institutional construct - in this instance, the standard of physical presence as the customary means of entering a full appearance at trial.

Moreover, videoconferencing contributes even more directly to a new regime for public trials, because in the case of a trial by videoconferencing, only the main site of the trial, the courtroom in the courthouse, is in fact open to the public. The other location - a library, a meeting room in another courthouse, or a fortiori a correctional facility - is not set up to accommodate the public. Attending a hearing therefore amounts to witnessing and being able to attest to only some of the circumstances under which it took place. What happens in the remote location cannot be seen except through what is shown on the screen; what happens outside the frame disappears, and what is in the frame is in fact staged by the act of framing itself (type of shot, zooming, etc.). The witnesses are therefore captive to what is shown them.

In fact, for our experiment with recording hearings by videoconferencing, we had to obtain two different authorizations: one to film the courtroom site, and another, much harder to obtain, to film at the remote site - in this case, a correctional facility. In practice, although connected by videoconferencing and jointly constituting the hearing, the two sites are undeniably governed by different rules regarding publicness.

\section{Conclusion: Cameras... and Their Uses}

Filming and transmitting hearings on the one hand, and conducting them by videoconferencing on the other, are generally addressed in different ways and through different analytical lenses. In this paper we have used the French experience to show that, in fact, the two activities share a number of features and tend to influence one another.

The genesis of videoconferencing in French judicial hearings is a key to understanding why no controversy has really emerged. Advocates promoted

${ }_{36}$ See, for example, "using this means of audiovisual telecommunication, which is nothing but a mode of personal appearance”, Cass. Crim., no. 13-85013, 1 Oct. 2013. 
the implementation of videoconferencing by dodging the issue of recording - although audio and video recording was technically possible with videoconference devices. In a sense, they neutralized the recording capability of cameras. Rather, they based their innovation on a legal argument centered on the precedent of videotaped testimonies already in force. But what is truly interesting is that the development of videoconferencing is indeed an indirect but concrete step toward weakening the impact of the main text (a 1881 law modified by a 1954 act) prohibiting the recording, filming and broadcasting of French hearings.

This leads us to underline the fact that the assertion that cameras are not allowed in French courtrooms - which sounds obvious in a way - is based on a narrow understanding of what cameras are and what can be done with them. The general principle remains written in the law as a general statement, but first, there are more and more exceptions for journalists and researchers and, further, a discrete exception - which could be a decisive one if it takes off - has been introduced with videoconferencing. This calls for analyzing a variety of technologies that at first sight do not seem to be linked but which are intertwined at the empirical level. It also suggests that ancillary innovations - such as videoconferencing - are sometimes bound to cause major transformations in the concept of what constitutes a trial.

In addition, by comparing the issues of filming hearings and videoconferencing, we have shown that what prevents the prohibition on filming from being lifted is not a rejection of technology nor any misgivings on the score of bringing cameras into the courtroom. In fact, whether hearings are filmed as part of conducting them or, as in our case, for research purposes, cameras are now authorized and accepted, and are sometimes even installed by the institution itself. The more difficult issue, and one which continues to be an obstacle, is the use that will be made of the images once a media mindset, often presented as hard to square with the judicial mindset, takes hold.

Edited by João Paulo Moreira

\section{References}

Adkins, Mary E. (2010), “The Unblinking Eye Turns to Appellate Law: Cameras in Trial Courtrooms and Their Effect on Appellate Law", Journal of Technology Law \& Policy, 15(65), 63-80.

Ares, Charles E. (1981), "Chandler v. Florida: Television, Criminal Trials, and Due Process”, The Supreme Court Review, 1, 157-192. 
Babcock, Emily; Johansen, Kate (2011), "Remote Justice? Expanding the Use of Interactive Video Teleconference in Minnesota Criminal Proceedings", William Mitchell Law Review, 37(2). Badinter, Robert; Wieviorka, Annette (2002), "Justice, image, mémoire”, Questions de communication [online], 1. DOI: 10.4000/questionsdecommunication.6507.

Biolley, Sophie de (2013), "La vidéo-comparution en Belgique: une solution sans problème”, Déviance et Société, 37(3), 305-321. DOI: 10.3917/ds.373.0305.

Bossan, Jérôme (2011), "La visioconférence dans le procès pénal: un outil à maîtriser", Revue de sciences criminelles, 4, 801-816.

Braun, Sabine (2013), "Keep Your Distance? Remote Interpreting in Legal Proceedings: A Critical Assessment of a Growing Practice”, Interpreting, 15(2), 200-228. DOI: 10.1075/intp.15.2.03bra.

Bussy, Florence; Bragança, Cédric de (2012), "Les images du procès et l'entrée des caméras dans les salles d'audience: dialogue entre un juriste et un réalisateur", LEGICOM, 48(1), 83-87. DOI: 10.3917/legi.048.0083.

Camp, Allen F. (1982), “Chandler v. Florida: Cameras, Courts, and the Constitution”, Pepperdine Law Review, 9(1), 165-195.

Coulon, Jean-Marie (2004), "Interview", Droit \& Economie - Revue de l'association française des docteurs en droit, 92 (Nov.), 6.

Danet, Jean (2010), La justice pénale entre rituel et management. Rennes: Presses universitaires de Rennes.

Diamond, Shari; Bowman, Locke; Wong, Manyee; Patton, Matthew (2010), "Efficiency and Cost: The Impact of Videoconferenced Hearings on Bail Decisions", Journal of Criminal Law and Criminology, 100(3), 869. DOI: 10.2307/25766111.

Dumoulin, Laurence; Licoppe, Christian (2013), "Innovation, routinisation et gestion de l'imprévu dans les audiences par visioconférence”, Déviance et Société, 37(3), 323-343. DOI: $10.3917 /$ ds.373.0323.

Dumoulin, Laurence; Licoppe, Christian (2016), "Videoconferencing, New Public Management, and Organizational Reform in the Judiciary", Policy E Internet, 8(3), 313-333. DOI: 10.1002/poi3.124.

Epineuse, Harold; Gheorghe, Oana; Villez, Barbara (2010), "La caméra dans le prétoire: information, transparence, interaction?”, Circav, 21, 149-166.

Feigenson, Neal; Spiesel, Christina (2009), Law on Display: The Digital Transformation of Legal Persuasion and Judgment. New York / London: NYU Press [republished in 2011]. Garapon, Antoine (2001), Bien juger. Essai sur le rituel judiciaire. Paris: O. Jacob.

Garre, Miguel (2013), "Captation vidéo des audiences en Espagne et droit à l'oubli: forces et faiblesses de l'acte électronique”, Revue Lamy Droit de l'Immatériel, 100(3337). Accessed on 06.04.2017, at http://www.adij.fr/donneespersonnelles/wp-content/ uploads/2015/01/1501-Vistas.pdf.

Garofano, Anthony (2007), “Avoiding Virtual Justice: Video-teleconference Testimony in Federal Criminal Trials”, Catholic University Law Review, 56(2). 
Garthwaite, Peter (2014), "Chandler v. Florida: Media in the Courtroom within the Purview of the $14^{\text {th }}$ Amendment", Grove City College Journal of Law and Public Policy, 5, 47. Gertner, Nancy (2004), "Videoconferencing: Learning Through Screens”, William \& Mary Bill of Rights Journal, 12(3). Accessed on 06.04.2017, at http://scholarship.law. wm.edu/wmborj/vol12/iss3/11.

Henning, Florian; Ng, Gar Yein (2009), "The Challenge of Collaboration - ICT Implementation Networks in Courts in The Netherlands", Transylvanian Review of Administrative Sciences, 5(28), 27-44.

Humbert, Sylvie (2010), “Cinéma et procès: l'arrivée de la caméra dans le prétoire”, Histoire de la justice, 20, 139-145.

Kodek, Georg E. (2012), "Modern Communications and Information Technology and the Taking of Evidence”, in Miklós Kengyel; Zoltán Nemessányi (eds.), Electronic Technology and Civil Procedure: New Paths to Justice from around the World, 261-278.

Lanzara, Giovan Francesco; Patriotta, Gerardo (2001), “Technology and The Courtroom: An Inquiry into Knowledge Making in Organizations”, Journal of Management Studies, 38(7), 943-971. DOI: 10.1111/1467-6486.00267.

Lederer, Fredric I. (2005), “Courtroom Technology: A Status Report”, in Kamlesh N. Agarwala; Murli D. Tiwari (eds.), Electronic Judicial Resource Management. New Delhi: MacMillan.

Lederer, Fredric I. (2009), “The Legality and Practicality of Remote Witness Testimony”, The Practical Litigator, 20(5), 19-30.

Machura, Stefan; Robson, Peter (2001), “Law and Film: Introduction”, Journal of Law and Society, 28(1), 1-8.

Marder, Nancy S. (2011), “The Conundrum of Cameras in the Courtroom”, 44 Arizona State Law Journal 1489. Accessed on 06.04.2017, at http://papers.ssrn.com/abstract $=1969115$.

Miniato, Lionel; Flores-Lonjou, Magali (2013), "Le procès dans le cinéma français", in Wanda Mastor; Lionel Miniato (eds.), Les figures du procès au-delà des frontières. Paris: Dalloz, 105-135.

Minjoz, Jean (1953), “Bill no. 5353”, Journal officiel. National Assembly, Parliamentary Documents, Session of 23 January 1953, p. 53.

Minjoz, Jean (1954), "Speech by the rapporteur of the justice and legislation committee”, Journal officiel. Fourth Republic, National Assembly, Parliamentary Debates, Session of 1 December 1954.

Mulcahy, Linda (2010), Legal Architecture: Justice, Due Process and the Place of Law. Abingdon, UK: Routledge.

Nesson, Charles R.; Koblenz, Andrew D. (1981), "Image of Justice: Chandler vs. Florida”, Harvard Civil Rights - Civil Liberties Law Review, 16, 405-413.

Patterson, Paul A. (1982), "Sixth Amendment, Televising Trials, Chandler v. Florida”, Akron Law Review, 15(1), 183-190. 
Porter, Elizabeth G. (2014), “Taking Images Seriously”, Columbia Law Review, 114(7), 1687-1782.

Rowden, Emma Louise (2013), "Virtual Courts and Putting 'Summary' Back into 'Summary Justice': Merely Brief, or Unjust?”, in Jonathan Simon; Nicholas Temple; Renée Tobe (eds.), Architecture and Justice: Judicial Meanings in the Public Realm. Farnham: Ashgate, 101-113. Accessed on 06.04.2017, at http://hdl.handle.net/10453/29898.

Salyzyn, Amy (2012), "A New Lens: Reframing the Conversation about the Use of Video-conferencing in Civil Trials in Ontario”, Osgoode Hall Law Journal, 50(2), 429-463.

Sécail, Claire (2010), "De la loi du 6 décembre 1954 au rapport Linden (2005): vers le retour des caméras dans le prétoire?”, Le temps des médias, 15(2), 269-284. DOI: 10.3917/tdm.015.0269.

Sherwin, Richard K. (2000), When Law Goes Pop: The Vanishing Line between Law and Popular Culture. Chicago: University of Chicago Press.

Sherwin, Richard K. (2004), "Law in Popular Culture", in Austin Sarat (ed.), The Blackwell Companion to Law and Society, 95-112.

Silbey, Jessica (2001), "Patterns of Courtroom Justice", Journal of Law and Society, 28(1), 97-116.

Silbey, Jessica (2002), "What we do When we do Law and Popular Culture", Law \& Social Inquiry, 27(1), 139-168.

Silbey, Jessica (2004), "Judges as Film Critics: New Approaches to Filmic Evidence”, University of Michigan Journal of Law Reform, 37, 493-571.

Sontag-Koenig, Sophie (2012), "Intervention de l'avocat et droits de la défense en garde à vue: quel avenir pour les enregistrements audiovisuels?”, Actualité juridique pénal, 10, 527-531.

Stepniak, Daniel (2004), "Technology and Public Access to Audio-visual Coverage and Recordings of Court Proceedings: Implications for Common Law Jurisdictions", William \& Mary Bill Rights Journal, 12, 791-823. Accessed on 05.04.2017, at http:// scholarship.law.wm.edu/wmborj/vol12/iss3/12.

Surette, Ray (2007), Media, Crime, and Criminal Justice: Images, Realities, and Policies.

'Contemporary Issues in Crime and Justice' Series. Belmont, CA: Thomson/Wadsworth [3 $3^{\text {rd }}$ edition].

Villez, Barbara (2009), Television and the Legal System. New York: Routledge.

Wallace, Anne (2008), “Virtual Justice in the Bush': The Use of Court Technology in Remote and Regional Australia”, Journal of Law, Information and Science, 19, 1-21.

Wiggins, Elizabeth C. (2003), "What we Know and What we Need to Know about the Effects of Courtroom Technology”, William \& Mary Bill of Rights Journal, 12, 731. Wiggins, Elizabeth C. (2006), "The Courtroom of the Future is Here: Introduction to Emerging Technologies in the Legal System”, Law \& Policy, 28(2), 182-191. DOI: 10.1111/j.1467-9930.2006.00222.x. 
Received on 29.10.2016

Accepted for publication on 23.03.2017

\section{Laurence Dumoulin}

UMR PACTE - CNRS, Institut d'études politiques de Grenoble

BP 48, 38040 Grenoble cedex 9, France

Contact: laurence.dumoulin@umrpacte.fr

\section{Christian Licoppe}

Département sciences économiques et sociales, Centre de recherche pluridisciplinaire du numérique, Télécom ParisTech

46 rue Barrault, 75013 Paris, France

Contact: christian.licoppe@telecom-paristech.fr

\section{Compreender a ténue ligação entre a filmagem e a transmissão numa sala de audiências. Considerações sobre o caso francês}

A filmagem e transmissão de audiências, por um lado, e por outro lado a realização destas por videoconferência são fenómenos que, de um modo geral, têm vindo a ser abordados com base em perspetivas analíticas distintas. O presente artigo visa servir-se da experiência francesa para demonstrar que, em verdade, ambos apresentam caraterísticas comuns. Procuramos, assim, pôr em evidência as ligações empíricas efetivas, ainda que discretas, verificadas no caso francês, bem como sublinhar algumas problemáticas suscitadas, quer pela própria ideia de audiência, quer pelas diferentes conceções daquilo que é estar presente e participar numa audiência e conferir-lhe caráter público.

Palavras-chave: audiências públicas; direito; filmagem; transmissão; videoconferência.

\section{Saisir le lien discret entre filmer et réaliser une visioconférence dans une salle d'audience. Réflexions à partir du cas français}

Filmer et retransmettre des audiences d'une part et les réaliser par visioconférence d'autre part sont, en général, abordés à travers des prismes analytiques séparés. À partir du cas français, cet article s'attache à démontrer que les deux activités présentent des caractéristique communes. Nous prétendons ainsi mettre en lumière les liens, réels bien que discrets, que ces deux activités entretiennent empiriquement en France. Nous mettons aussi en évidence quelques problématiques convergentes, autour de la notion d'audience d'abord, et des différentes conceptions de la présence, de la participation à l'audience et de la publicité de celle-ci, ensuite.

Mots-clés: audiences publiques; droit; filmage; transmission; visioconférence. 